\title{
Assessing the Effects of the Mobile Money Service on Small and Medium Sized Enterprises: Study on EVC-Plus Services in Somalia
}

\author{
Abdinur Ali Mohamed*, Mohamed Ibrahim Nor \\ Faculty of Economics, SIMAD University, Mogadishu, Somalia \\ Email: *abdinur@simad.edu.so, *Cabdinur80@gmail.com
}

How to cite this paper: Mohamed, A. A., \& Nor, M. I. (2021). Assessing the Effects of the Mobile Money Service on Small and Medium Sized Enterprises: Study on EVCPlus Services in Somalia. American Journal of Industrial and Business Management, 11, 499-514.

https://doi.org/10.4236/ajibm.2021.115031

Received: April 21, 2021

Accepted: May 22, 2021

Published: May 25, 2021

Copyright $\odot 2021$ by author(s) and Scientific Research Publishing Inc. This work is licensed under the Creative Commons Attribution International License (CC BY 4.0).

http://creativecommons.org/licenses/by/4.0/ (c) (i) Open Access

\begin{abstract}
The development of the mobile money services permits the businesses and the individuals to get access to the financial services and become part of the financial system. Access to the financial system is a key drive to business growth and entrepreneurial development in Somalia and in many parts of the world. The purpose of this study was to examine the contribution of the mobile money services to the growth of the small and the medium sized enterprises in Somalia. We applied dynamic capability theory to examine the factors that affect the business growth. This study employed cross sectional research design and used quantitative techniques to analyze the data of the study. The target population of the study was business owners that are in major cities in Somalia. A sample of 138 business categorized by trade, services and manufactures were studied. Descriptive and the inferential statistics were used to analyze the cross-section data collected from the various respondents. For regression analysis, Robust Least Squares (ROBUSTLS), is used to estimate the model parameters of the study. We rejected null hypothesis examined by this study and we found that all variables have a positive contribution that is different from zero and being statistically significant. The result shows that a one percent increase of the access to finance contributes to business grow of about $(0.186 \%)$ while a $(1 \%)$ increase sales growth, leads business to grow about $(0.183 \%)$. The enhancement of the risk management by (1\%) increases business grows to about $(0.225 \%)$. The product development is a dominant variable that leads to business growth as $(1 \%)$ increase of the product development, leads business to grow about $(0.254 \%)$. These results indicate that mobile money service has a positive and significant influence to the business's ability to access the finances. The increase of the mobile money adoption by
\end{abstract}


(1\%), causes access to the finance to increase about (13\%). Mobile money also contributes to the sales growth as a (1\%) increase of the use of the mobile money, causes sales to surge by (3\%). Results show that a (1\%) increase of the use of mobile money, leads the risk management to improve about (4\%) and that a (1\%) increase of the mobile money services, leads the product development to increase to about (9\%). The stability of the data was examined using CUSUM test and we found that the data is stable. The model has no multicollinearity problem and the heteroskedasticity and the serial correlation were corrected.

\section{Keywords}

Dynamic Capability Theory, Business Growth, Mobile Money Services, EVC-Plus

\section{Introduction}

Mobile money service is an effective instrument to further growth of the Small and the Medium Size Enterprises (SMEs), and to promote the innovation to spillover across the emerging markets. The development of the mobile money services enables the businesses and the individuals to get access to financial services and become part of the financial system. Access to the financial system is a key driving force towards business growth and entrepreneurial development. The growth of the small and the medium enterprises have a ripple effect on the country's Economic Growth as they create employment, enhance income and improve purchasing power of the households (Barrett \& Burgess, 2008). Mobile phones are an affordable tool for communication and for money transfer with an ample ability to achieve a large number of populations in widely dispersed areas. Mobile money service enhances access to the financial institution, helps the transfer of money, allocation of the capital, monitoring of the finances and the risk management (Demirguc-Kunt, Klapper, Singer, \& Van Oudheusden, 2015).

The small and medium sized enterprises largely rely on the mobile money service to buy from the suppliers, pay the bills and the storing of finances. Merchants opt to use mobile money services since it is cheaper to transfer money and safer, with the ability to track the transactions and check the payment references. According to the (World Bank, 2017) mobile money is expanding by volume and value and is dominating the ecosystem in Somalia as it helps business organizations enter the ecosystems and survive within it. In addition to that, mobile money is the prominent payment system in Somalia as (30\%) of the money transfers are person to person payment, and about (29\%) of it are merchant payments. Businesses also use mobile money to pay the bills as (72.6\%) of the mobile money transfers are bill payments and (15\%) of the users use mobile money to store finances. Mobile money supports businesses to reduce the li- 
quidity issues by enabling businesses access to their business accounts.

Somalia is among the countries in the sub-Sahara which have a high penetration of mobile phones. About (73\%) of the population above the age of 16 use mobile services. About (63\%) of the mobile subscribers use mobile phones to save money and transfer it. Hormuud telecom dominates the mobile money services in the south and central Somalia. Hormuud offers EVC-Plus services which continue to be a widely accepted means of payment and to store money. Somalis positively perceive mobile money services and the satisfaction rate is about $92 \%$ (World Bank, 2017). EVC-Plus is an appropriate alternative to the banking services which are available only to (15.5\%) of the population. Shifting the digital payment improves the payment efficiency and speeds the transactions in the benefit of the businesses and the households.

Despite the substantial increase of the literature on mobile money and its impact on the economy and the financial system, little is known about the and conceptual development of the phenomenon of business growth and the mobile money service. Studies that examined the mobile money services have extensively concentrated on the consumer level (Jack and Suri, 2011). There is a need to study the effect of the mobile money service towards business enterprises to explicitly discover the contribution of the mobile money to business growth and its role of facilitating the entrepreneurial development. The purpose of this study is to examine the contribution of the mobile money towards access of finance, sales growth, risk management and the product development. The rest of this paper is structured as follows; second section is the literature review, the third section is the research methodology, the four section is the result and the discussion, the fifth section is the conclusion and the recommendation.

\section{Review of the Related Literature}

The growth and the development of the SMEs have long been the focus of the researchers in regards to their contribution to the economy and the complex factors that affect them. Previous literature evidences that mobile money promotes the business's access to finance. The access to the finance and the availability of financial resources is a key driver of the business's growth. Many studies focused on the nexus of finance and the business growth, such studies include, (Hartarska and Gonzalez-Vega, 2006) who found that the lack of access to the financial resources limited the growth of business. Bamford et al. (1997) stated that financial resource is the common type of resource that can be used in all other resources, so the access to the financial capital helps the business grow and reach a better performance. Coad et al. (2013) argued that access to the financial resources is a major determinant of the business growth since financial resources are used to improve business capacity. Jones and Tilley (2003) and Shakantu \& Kajimo-Shakantu (2007) listed factors that impede the business from growth, and the limited access to the finance was the top factor that limited business growth. Krasniqi (2007) examined SMEs burdens and found that an insufficient financial capital, tax burden and unfair competition diminished business growth 
in Kosovo. Kyophilavong (2011) investigated the constrains of the SMEs growth and found that the lack of the assets due to inadequate financial resources tackled the advancement of the SMEs. Ejembi and Ogiji (2007), Thornhill and Amit (2003) stated that readily available financial resources is an important factor that leads the business towards growth and development. Alam et al. (2011), examined the growth barriers of the SMEs in Malaysia and the found that the lack of the access to financial resources had a negative impact on the SMEs growth. Okpara and Wynn (2007) found that the lack of the financial support and inadequate managerial experience are major determinants of business growth. Previous literature evidenced that mobile money facilitates access to the financial capital and facilitates the process of the financial transfers. Mobile money also increases the transactions and enhances the sales of the business which is a key factor for business growth. Several studies highlighted these issues, such as: Achtenhagen et al. (2010) examined growth attributes of the business and found that increases in sales and in asset growth indicators of the SMEs business. Rauch and Rijskik (2013) examined the measures of the business growth and found that increased sales and the turnover are basic measures of the business growth. Delmar et al. (2003), Coad (2007) has stated that an increase of sales, profit and the employees are the indicators of the business growth. McGrath (2001) stated that risk is related to the SMEs performance and businesses which risks succeeds to achieve a significant performance. Davidsson and Wiklund (2006) demonstrated the growth prospects of the small business and suggested that business growth depends on the business activities and the administrative structure of the businesses. Lewin and Regine (1999) found that business is a part of the many economic actors and their success is dependent on other economic entities. Bosma, van Praag, Thurik, \& De Wit (2004) stated that there are several antecedents of business growth such as human and social capital and innovation. Bartoloni \& Baussola (2018) argued that the product development and the innovation are also key drivers of the SMEs performance and the growth. Previous studies present that mobile money transfer supports the business growth and helps the business owner send, receive, save and deposit money to areas where banking and the remittance services are not available. According to Jack \& Suri (2014), mobile money helped entrepreneurs in remote areas to have access to the financial resource and make payments through the mobile money. Aker \& Mbiti (2010) stated that people use mobile money in the place of cash and send electronic money to any person. Murphy (2016) argues that mobile money permits the people to store value, send and receive money without using the traditional bank account. Kasseeah and Tandrayen-Ragoobur (2012) stated that mobile money is used by consumers to buy goods and bill the payments. Mohamed and Nor (2020) examined Mobile Money and economic activities in Somalia and found that mobile money promoted consumer spending and raised the household income in Somalia. Previous literature shows that there is a link between mobile money and the access to the finances and business growth. The literature also shows that mobile money is linked to the sales growth, risk reduc- 
tion and the product development.

\section{Theoretical Framework and Hypothesis Development}

This study utilizes the dynamic capability theory initially developed by Teece, Pisano and Shuen (1997). Dynamic capability explains how available resources and competence can be managed and utilized. The theory goes further to present the ability to build and integrate the internal and the external capability to cope with the rapidly changing business environment. The dynamic capability theory can be expanded to explain the capacity of the business to realize the then threats, grasp the opportunities, and combine the internal and the external resources to stay competitive. The dynamic capability theory can be integrated to the capability of the mobile money to get access to the finances and increase the sales and reduce the risk. Wade and Hulland (2004) stated that mobile money can be an internal resource since it can be used to access the financial capital, transfer money to the suppliers and receive money from the customers. Additionally, mobile money is used to keep the ledger records and to save money for future transactions. Mobile money is also an external resource that can provide the commercial bank service and the remittance as well. Wang and Ahmed, (2007), Teece (2007) and Winter (2003), applied the dynamic capability theory to examine the business growth. Capability of the mobile money to transfer money and serve other functions of money can consolidate the ability of the business to gain access to the financial resources and boost the business growth. The following Figure 1 shows the interactions of the mobile money and business growth.

Several previous studies, Asamoah, Takieddine, \& Amedofu (2019) applied the dynamic capability theory and stated that mobile service integrates to the business's internal and external resources and amplifies the ability of the business to grow. The figure exhibits that mobile money is linked to the business's ability to get access to the financial capital by reducing the borrowing process from external sources and the banks. Mobile money also increases sales by boosting consumer spending, and supports the business to manage the risk by improving the internal control procedure of the business. Mobile money is also linked to the product development and the innovation by helping the business make the right investment. Based on the provision of the dynamic capability theory, this study develops the following hypothesis.

$\mathrm{H1}$ : There is no significant relationship between mobile money and the business growth.

H2: There is no significant relationship between mobile money and the business's access to the finances.

H3: There is no significant relationship between mobile money and the business's sales growth.

H4: There is no significant relationship between the mobile money and the business's risk management. 


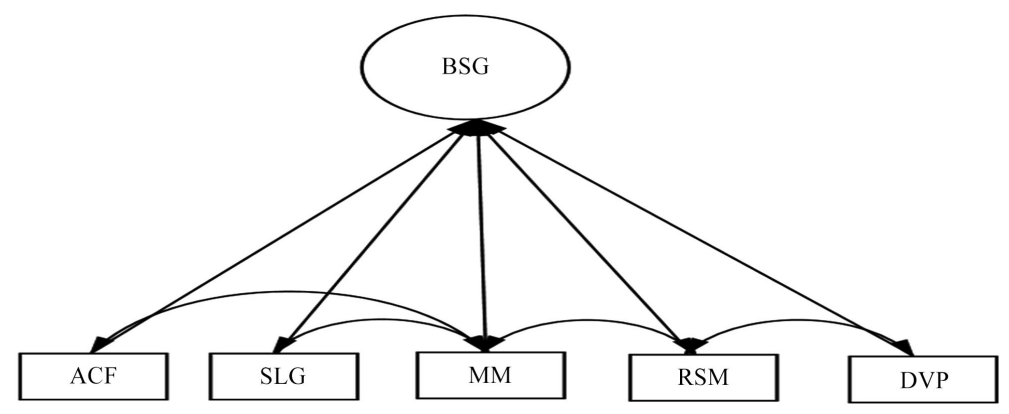

Figure 1. Link between mobile money and the factors of the business growth.

H5: There is no significant relationship between mobile money and the business's product development.

Regression analysis will be used to calculate the parameters of these hypothesis. Probability value ( $\mathrm{p}$-value) will be used to test the hypothesis, $\mathrm{P}$-value will be compared to the $(5 \%)$ of significance level. Each hypothesis with P-value less than $(5 \%)$ will be rejected while the P-value greater than (5\%) will not be rejected.

\section{Research Methodology}

This study applies a cross sectional design to measure the contribution of the mobile money to the business growth and to examine the hypothesis generated in this study. Cross sectional design is opted to investigate the outcome and the exposure of the studies participant at the point of time. The study used quantitative methods to collect the data from the dispersed population and the diverse business organization, so this study employs both descriptive and the analytical techniques. The owner and managers of the SMEs at the major cities in Somalia are the target populations of this study. Due to the frequency of the business entries and the exits, it is not straight forward to track the target population of this study, and it is treated as an infinite population. The Confidence interval method is used to determine the sample size. We calculated the sample size using 95 percent of the confidence internal and the 5 percent of the margin of error. A Sample of 138 of SMEs participated in this study. The size of the sample is also determined by factors including the willingness of the business owners to disclose the effect of the mobile money to their business performance, formality of the business transactions and longevity of the business. The combination of these factors limited the size of the sample., purposive sampling method was used to reach out to the study participants.

The variables of this study are the business growth, access to finances, sales growth, risk management, mobile money and the product development. Business growth is measured to four items and those are; the ability to access the finance, time frame of getting finance, process of getting finance and the sources of the finance. Sales growth is also measured in four items and those are; the trends of the sales, directions of the sales, volume of the sales, and the transac- 
tion cost of the sales. Risk management is also measured in four items and those are; the probability of fraud, the probability of misappropriation, the improvement of the internal control and the safety of the transactions. The product development is measured in four items and those are; product development, change of the product lines, the extent of the changes of the product lines and the introduction of the new products or services. Mobile money is also measured in four items those are; easiness of the mobile money services, skills required to transfer money, communicability of the mobile money service providers, and the recoverability of the wrong transfers.

Several previous studies used these criteria to measure business growth and the mobile money service, such studies include: Andoh-Baidoo, 2016; Wiklund et al., 2009 and Asamoah, Takieddine \& Amedofu, 2019. A questionnaire was used to collect the cross-section data of this study. The questionnaire was structured using modified Likert scale. The descriptive statistics is used to describe the constructs of the study, mean and the standard of each factor is calculated. Regression analysis, especially robust least square (ROBUSTLS) analysis is used to estimate the intercept and the coefficients of the model. ROBUSTLS is preserved due to its less restrictive assumption. This method works well when outlier are in the data. Outliers violate the assumption of the normal distribution of the residuals in the ordinary least squares.

\section{Model Specification}

The model of this study is developed utilizing from the dynamic capability theory. ROBUSTLS is used to estimate the parameters of this model specified as follows:

$$
\begin{aligned}
\operatorname{InBSG}_{i}= & \beta_{0}+\beta_{\mathrm{ACF}} \ln \mathrm{ACF}_{i}+\beta_{\mathrm{SLG}} \ln \mathrm{SLG}_{i}+\beta_{\mathrm{USG}} \ln \mathrm{RSM}_{i} \\
& +\beta_{\mathrm{MM}} \ln \mathrm{MM}_{i}+\beta_{\mathrm{PDV}} \ln \mathrm{PDV}_{i} u_{i}
\end{aligned}
$$

Where, BSG is business growth, ACF is access to finance, SLG is sales growth, RSM is risk management, MM is mobile money, PDV is number of observations and $\mathrm{u}$ is error term. Structural Equation Method (SEM) will be used to estimate the contribution of the mobile money and the factors of the business growth.

\section{Results and the Discussion}

This study targeted business managers/owners with diverse forms of business located all over the major cities in Somalia. Study reached out 138 participants while 131 out of the 138 responses were returned assuring a high response rate. The reliability of the data was examined using Gutman Lambda for all of the factors, and the result showed that reliability of the factors was in between 0.716 - 0.854, meaning that the data of the study is in the reliable range. The reliability of the value of ACF was ACF (0.716), MM (0.780), SLG (0.845), RSM (0.749), PDV (0.775). Demographic variables of the respondents were examined and the result is presented in the below Table 1 . 
Table 1. Demographic characteristics of the respondents.

\begin{tabular}{|c|c|}
\hline Factors & Percentage \\
\hline \multicolumn{2}{|l|}{ Gender } \\
\hline Male & 62 \\
\hline Female & 38 \\
\hline \multicolumn{2}{|l|}{ Age Group } \\
\hline $25-35$ & 50.4 \\
\hline $36-45$ & 38.9 \\
\hline 46 and Above & 10.7 \\
\hline \multicolumn{2}{|c|}{ Educational background } \\
\hline Secondary Level & 5.3 \\
\hline Bachelor degree & 80.2 \\
\hline Master degree & 14.5 \\
\hline \multicolumn{2}{|l|}{ Business Type } \\
\hline Trade & 58.7 \\
\hline Services & 20.3 \\
\hline Manufacture & 19.6 \\
\hline
\end{tabular}

Table 1 shows gender, age groups, education level and the business types, of the respondents of this study. The table shows that males are about 60 percent while females are about 40 percent, indicating that women is a business up trending. Age group between 25 - 45 is dominant and makes about 90 percent of the business owners in Somalia. Result is indicating that the small and the medium sized business employs a substantial number of young populations in Somalia. The result also shows that most of the business owners have a university degree, generally, bachelor degree while some of them have a postgraduate degree and a very few have secondary school certificate. The young entrepreneurs that have a university degree are more likely to utilize mobile money services to run business, access their accounts and accept the mobile money as mode of payment for their business.

\subsection{Descriptive Statistics of the Variables}

Business growth is set to be driven by five factors those being; access to the finance, sales growth, risk management, mobile money usage and the product development. The descriptive statistics is used to calculate the means and the standard deviation of these variables and the result is presented in the below $\mathrm{Ta}$ ble 2.

Result in the table shows that the access to the finance has a mean (1.9528) and standard deviation (0.8610). The results indicate that respondents agree that mobile money elevates the ability of the business to access the finance and get the required capital through mobile money services. The mean of the mobile 
Table 2. Descriptive statistics of the input variables.

\begin{tabular}{ccc}
\hline Input Variables & Mean & Std. Deviation \\
\hline ACF & 1.9528 & 0.8610 \\
MM & 1.7736 & 0.7305 \\
SLG & 1.3029 & 0.3946 \\
RSM & 1.2971 & 0.4506 \\
PDV & 1.2172 & 0.3735 \\
\hline
\end{tabular}

money was (1.7736) and standard deviation (0.7305). This shows that business firms largely accept mobile money as means of payment. Sales growth's mean came to be (1.3029) and standard deviation (0.394) meaning the business owners agree that mobile money facilitates the transaction, influences the consumer's intentions to buy and pushed the sales volume.

The contribution of the mobile money to the risk management was also measured and we found the mean of (1.2971) and standard deviation (0.4506). The data presented that respondents were neutral about the contribution of the mobile money to the risk management. Product development was also another variable measured to the business growth. The mean of the product development got to be (1.2172) and standard deviation (0.3735). The role of the mobile money to the product development is moderate and neutrally influences the changes of the product lines and the innovations. Figure 2 shows the rank of the variables based on their contribution to the business growth.

Mobile money gives the largest contribution to access towards finances where the sales growth became the second most important recipient of the mobile money contribution. Risk management gets mild contribution from the mobile money. The application of the mobile money complements the business's internal control and the accounting manuals but cannot serve all functions of the risk management framework. Mobile money has a contribution to the business's product development initiatives. The change of the product lines and the ability of the businesses to innovate is affected by many interrelated factors those being both financial and none financial. Mobile Money can support the financial aspects of the product development. A recent trend on the markets in Somalis economy; is development of online businesses. Mobile money has assets in e-markets and the delivery-businesses that largely rely on the mobile money services to execute online transactions.

\subsection{Result of the Model Parameters and the Hypothesis Testing}

The model parameters were tested using regression methods. ROBUSTLS method was used to estimate the intercept and the coefficient model and the result is presented in Table 3.

All the variables of this study are statistically significant and are different from zero meaning that they all have a positive contribution to the business growth. 




Figure 2. Rank of the variables according to their means.

Table 3. Estimated parameters of the model.

\begin{tabular}{ccccc}
\hline Variable & Coefficient & Std. Error & t-Statistic & Prob. \\
\hline BSG & 1.6471 & 0.0054 & 303.39 & 0.0000 \\
$\ln (\mathrm{ACF})$ & 0.1875 & 0.0096 & 19.505 & 0.0000 \\
$\ln (\mathrm{SLG})$ & 0.1821 & 0.0085 & 21.423 & 0.0000 \\
$\ln (\mathrm{RSM})$ & 0.2233 & 0.0056 & 39.767 & 0.0000 \\
$\ln (\mathrm{MM})$ & 0.1668 & 0.0076 & 21.739 & 0.0000 \\
$\ln (\mathrm{PDV})$ & 0.2564 & 0.0048 & 52.712 & 0.0000 \\
\hline
\end{tabular}

We rejected all of the five hypothesis which shows that sales growth, risk management, mobile money and the product development are positively linked to the business growth. $\mathrm{R}$ square is 0.97 indicating that $97 \%$ of the variations of the business growth results from the variables considered in this study and only $3 \%$ are from the error term. The joint significance of the model is also tested and the F statistics is statistically significant meaning that these variables make joint significance. The model problems were diagnosed and we didn't find any sign of the perfect collinearity, the constancy of the variance was checked by examining the heteroskedasticity through Breusch-Pagan-Godfrey method. We rejected the null hypothesis and found that the model has the problems of the heteroskedasticity which was then corrected through the white test and standard deviation was changed to the standard robust test. The presence of the serial correlation was also detected and then HAC method was used. The stability of data was examined through CUSUM test, and we found that the data is stable.

The result shows that a (1\%) increase of the access to finance contributes to business growth about (0.186) percent while an increase of sales growth, leads business to grow about $(0.183 \%)$. The enhancement of the risk management by (1\%), increases business to grow about $(0.225 \%)$. The contribution of the mobile money to business growth was also measured and found that (1\%) rise of the mobile money adoption, causes the business to grow about $(0.168 \%)$. The product development is a dominant variable that leads to business growth and a (1\%) increase of the product development, leads the business to grow about $(0.254 \%)$. Product development helps the business charge high prices and increase the profit margins which may help businesses to reduce the debt and grow consi- 
derably. The result of the study presents that business growth results from the access of the finance, sales growth, mobile money services, risk management and the produce development. We go further to determine how mobile money contributes to the access of the finance, sales growth, risk management and the product development. To that purpose we estimated the correlation coefficients and the covariance of the independent variables, and the result of the path coefficients, is presented in Figure 3.

The result in the Figure 3 shows that indicates that mobile money services has a positive and significant influence to the business's ability to access the finances. The rise of the usage of mobile money by (1\%), causes the access to the finance to increase about (13\%). This result reflects the fact that small businesses lack the ability to use banking service because it is costly to them or banks are not available in the business locations. Mobile money also contributes to the financial inclusion of the business owners which in turn help them receive investment capital, send and receive money from the various sources in a short period of time. Mobile money also supports small businesses to save money to the banks and to withdraw from it when the need arises. Figure 3 also shows that mobile money contributes to the sales growth as (1\%) increase of the use of mobile money, causes sales to surge by about (3\%). Mobile money enhances the consumer's willingness to buy and increases the daily expenditure of the household. Mobile money enables consumers to easily transfer money and make transactions without carrying cash, which in turn leads the sales volume to rise. Mobile money is linked to the growth of the household income which elevates the effective demand of the consumers.

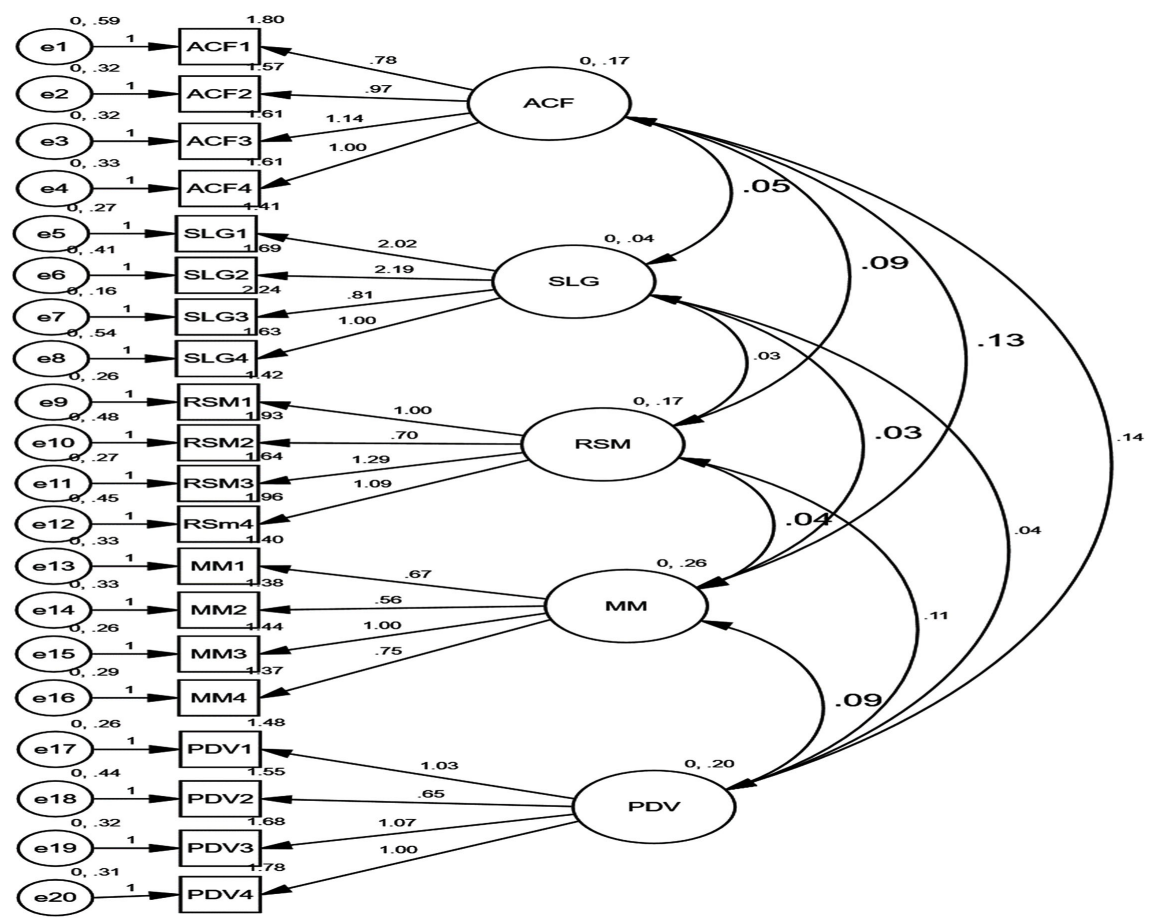

Figure 3. Path coefficients of the mobile money and the factors of the business growth. 
Mobile money is also linked to the risk management and the fraud prevention of the business organizations. Result shows that a (1\%) increase of the use of mobile money, leads risk management to improve about (4\%). Sizeable number of the small and medium sized businesses are unable to adopt standard accounting manuals and risk management framework. Mobile money services provide mechanisms to track the transaction and to deposit the income to the bank account just by using mobile money services. Mobile money also increases the safety of the transaction and reduces account errors as transaction messages are retrievable in future dates.

Product development initiative is supported by the mobile money services as evidenced by the data of this study. Result shows that a (1\%) increase of the mobile money services, leads product development to increase about (9\%). Mobile money services facilitate the business to get investment required to implement the innovation and change the product lines. Mobile money also inspired the surge of the online business where many small business accept online payment and delivered to customers by using mobile money services. Transportation and the food industries are the largest beneficiaries of the mobile money services which alternated the internet banking which is not inclusively available in Somalia.

The growth of the Small and Medium size business in Somalia is challenged by a multitude of factors that hastens business failure in Somalia. Such factors include the lack of access towards the finance and the low growth, and failure to diffuse the innovation. EVC-Plus which is the prominent mobile money services in Somalia, has proved to be a solution to the hinders of the business growth and its development. EVC-Plus provides access to finance, enhances financial inclusion, reduces the risk of fraud, promotes the sales and improves the product development initiatives. EVC-Plus also played a crucial role for minimizing the loss of the currency and the money mutilation those being the problems of the fait money.

The findings of this study are consistence with previous studies such as Koryak et al. (2015) who found that mobile money boosted the sales and enhanced the consumer spending. Anand and Sen (2000) that stated organizations ability to utilize the resource leads business growth and Asamoah, Takieddine, \& Amedofu (2019) who found that mobile money banked the unbanked businesses and culminated microentrepreneurs development.

\section{Conclusion}

The purpose of this study was to examine the contribution of the mobile money services to the growth of the small and the medium sized enterprises in Somalia. We applied dynamic capability theory to examine the factors that affect the business growth. Five factors are set to impact the business growth those are: access to finance, sales growth, mobile money, risk management and the product development. This study employed a cross sectional research design and used 
quantitative techniques to analysis the data of the study. The target population of the study was business owners that are in major cities in Somalia. Sample of 138 businesses categorized to trade, services and manufactures were studied. Purposive sampling technique was employed to approach the respondent. Descriptive and the inferential statistics were used to analyze the cross-sectional data collected from the various respondents. Regression analysis, ROBUSTLS, is used to estimate the model parameters of the study.

We rejected the null hypothesis examined by this study and we found that all Variables have a positive contribution that is different from zero and being statistically significant. The result shows that one percent increase of the access to finance contributes business grow to about $(0.186 \%)$ while (1\%) increase sales growth, leads businesses to grow about (0.183\%). The enhancement of the risk management by (1\%) increases business growth about $(0.225 \%)$. The product development is a dominant variable that leads to business growth as (1\%) increase of the product development, leads business to grow about $(0.254 \%)$.

The result indicates that mobile money service has a positive and significant influence to the business's ability to access to finances. The increase of the mobile money adoption by (1\%), causes access to finance to increase about (13\%). Mobile money also contributes to the sales growth as (1\%) increase of the use of the mobile money, causes sales to surge by (3\%). Result shows that (1\%) increase of the use of mobile money, leads risk management to improve about (4\%) and that $(1 \%)$ increase of the mobile money services, leads product development to increase about (9\%). The stability of the data was examined using CUSUM test and we found that the data is stable. The Model has no multicollinearity problem and the heteroskedasticity and the serial correlation were corrected. The future works on the mobile money business growth should use time series data on the business growth and development. Researchers should also focus on the sectoral effects of the mobile money and business growth by concentrating on the effect of the mobile money's various types of business.

\section{Recommendation}

- Mobile money has an enormous contribution to the growth of the small and medium sized enterprises in Somalia. So that mobile telecom companies should expand mobile money services to mitigate business's risk and prevent sim-card swaps in order to prevent the fraudulent business transactions and to safeguard business accounts from errors and the misappropriations.

- Financial institutions and the commercial banks that deal with small businesses, should develop a loan and the saving products that can be transacted via mobile money service to reach the rural areas where formal banks are not available or is hard to be reached. Financial institutions should align their services to the mobile money in order to reduce the problem of the inactive accounts.

- Business development service providers and the government institutions that promote business development should establish platforms for business en- 
terprises to share the information and the innovations of the mobile money apps so as to increase the business uses and the access to financial products and the trustworthiness of the mobile money services.

\section{Conflicts of Interest}

The authors declare no conflicts of interest regarding the publication of this paper.

\section{References}

Achtenhagen, L., Naldi, L., \& Melin, L. (2010). Business Growth: Do Practitioners and Scholar Really Talk about the Same Thing? Entrepreneurship Theory and Practice, 34, 289-316. https://doi.org/10.1111/j.1540-6520.2010.00376.x

Aker, J. C., \& Mbiti, I. M. (2010). Mobile Phones and Economic Development in Africa. The Journal of Economic Perspectives, 24, 207-232. https://doi.org/10.1257/jep.24.3.207

Alam, S. S., Jani, M. F., Senik, Z. C., \& Domil, A. K. (2011). Assessing Barriers of Growth of Food Processing SMIs in Malaysia: A Factor Analysis. International Business Research, 4, 252-259. https://doi.org/10.5539/ibr.v4n1p252

Anand, S., \& Sen, A. (2000). Human Development and Economic Sustainability. World Development, 28, 2029-2049. https://doi.org/10.1016/S0305-750X(00)00071-1

Andoh-Baidoo, F. K. (2016). Organizational Information and Communication Technologies for Development. Information Technology for Development, 22, 193-204. https://doi.org/10.1080/02681102.2016.1160703

Asamoah, D., Takieddine, S., \& Amedofu, M. (2019). Examining the Effect of Mobile Money Transfer (MMT) Capabilities on Business Growth and Development Impact. Information Technology for Development, 26, 146-161. https://doi.org/10.1080/02681102.2019.1599798

Bamford, C. E., Dean, T. J., \& McDougall, P. P. (1997). Initial Strategies and New Venture Growth: An Examination of the Effectiveness of Broad vs. Narrow Breadth Strategies, Frontiers of Entrepreneurship Research. Wellesley, MA: Babson College.

Barrett, R., \& Burgess, J. (2008). Small Firms and the Challenge of Equality, Diversity and Difference. Equal Opportunities International, 27, 213-220. https://doi.org/10.1108/02610150810860057

Bartoloni, E., \& Baussola, M. (2018). Driving Business Performance: Innovation Complementarities and Persistence Patterns. Industry and Innovations, 25, 505-525. https://doi.org/10.1080/13662716.2017.1327843

Bosma, N., van Praag, M., Thurik, R., \& de Wit, G. (2004). The Value of Human and Social Capital Investments for the Business Performance of Startups. Small Business Economics, 23, 227-236. https://doi.org/10.1023/B:SBEJ.0000032032.21192.72

Coad, A. (2007). Firm Growth: A Survey. Documents de travail du Centre d'Economie de la Sorbonner 07024, Université Panthéon-Sorbonne (Paris 1), Centre d'Economie de la Sorbonne.

Coad, A., Frankish, J., Roberts, R. G., \& Storey, D. J. (2013). Growth Paths and Survival Chances: An Application of Gambler's Ruin Theory. Journal of Business Venturing, 28, 615-623. https://doi.org/10.1016/j.jbusvent.2012.06.002

Davidsson, P., Delmer, F., \& Wiklund, J. (2006). Entrepreneurship and the Growth of Firms. Northampton, MA: Edward Elgar. https://doi.org/10.4337/9781781009949 
Delmar, F., Davidsson, P., \& Gartner, W. (2003). Arriving at the High-Growth Firm. Journal of Business Venturing, 18, 189. https://doi.org/10.1016/S0883-9026(02)00080-0

Demirguc-Kunt, A., Klapper, L. F., Singer, D., \& Van Oudheusden, P. (2015). The Global Findex Database 2014: Measuring Financial Inclusion around the World. Policy Research Working Paper No. 7255, Washington DC: World Bank. https://doi.org/10.1596/1813-9450-7255

Ejembi, S. A., \& Ogiji, P. (2007). A Comparative Analysis of Risks and Returns of Running Small/Medium and Micro Enterprises in North and Central Nigeria. Journal of Social Science, 15, 7-15. https://doi.org/10.1080/09718923.2007.11892556

Hartarska, V., \& Gonzalez-Vega, C. (2006). What Affects New and Established Firms' Expansion? Evidence from Small Firms in Russia. Small Business Economics, 27, 195206. https://doi.org/10.1007/s11187-006-0012-0

Jack, W., \& Suri, T. (2011). Mobile Money: The Economics of M-PESA. No. w16721, National Bureau of Economic Research. https://doi.org/10.3386/w16721

Jack, W., \& Suri, T. (2014). Risk Sharing and Transactions Costs: Evidence from Kenya's Mobile Money Revolution. The American Economic Review, 104, 183-223. https://doi.org/10.1257/aer.104.1.183

Jones, O., \& Tilley, F. (2003). Competitive Advantage in SMEs: Organizing for Innovation and Change. San Francisco, CA: Wiley.

Kasseeah, H., \& Tandrayen-Ragoobur, V. (2012). Mobile Money in an Emerging Small Island Economy. ARPN Journal of Science and Technology, 2, 454-461.

Koryak, O., Mole, K. F., Lockett, A., Hayton, J. C., Ucbasaran, D., \& Hodgkinson, G. P. (2015). Entrepreneurial Leadership, Capabilities and Firm Growth. International Small Business Journal: Researching Entrepreneurship, 33, 89-105. https://doi.org/10.1177/0266242614558315

Krasniqi, J. (2007). Can the State Replace Private Capital Investors? Discussion Paper, Budapest: Institute of Economics-Hungarian Academy of Sciences.

Kyophilavong, P. (2011). SMEs Access to Finance: Evidence from Laos. In C. O. Harvie, \& D. Narjoko (Eds.), Small and Medium Enterprises (SMEs) Access to Finance in Selected East Asian Economies (pp. 117-150). ERIA Research Project Report 2010-14, Jakarta: ERIA.

Lewin, R., \& Regine, B. (1999). The Soul at Work: Unleashing the Power of Complexity Science for Business Success. London: Orion Business.

McGrath, R. G. (2001). Exploratory Learning, Innovative Capacity, and Managerial Oversight. Academy of Management Journal, 44, 118-131. https://doi.org/10.2307/3069340

Mohamed, A. A., \& Nor, M. I. (2019). Measuring the Effect of the Mobile Money on Economic Activities in Somalia: Case of the Hormuud's Eve plus. Working Paper No. $1 / 4$.

Murphy, A. (2016). How Ghana Is Using Mobile Money to Go Cashless. http://www.africanbusinessreview.co.za

Okpara, J. O., \& Wynn, P. (2007). Determinants of Small Business Growth Constraints in a Sub-Saharan African Economy. Advanced Management Journal, 72, 24-37.

Rauch, A., \& Rijskik, S. A. (2013). The Effects of General and Specific Human Capital on Long Term Growth and Failure of Newly Founded Businesses. Entrepreneurship Theory and Practice, 3, 923-941. https://doi.org/10.1111/j.1540-6520.2011.00487.x

Shakantu, W. M. W., \& Kajimo-Shakantu, K. (2007). Harnessing the Informal and Formal SMME Construction Sectors Resolve the South African Construction Skills Shortage. CIB World Building Congress Construction for Development, Cape Town, 14-17 
May 2007, 2132-2139.

Teece, D. J. (2007). Explicating Dynamic Capabilities: The Nature and Microfoundations of (Sustainable) Enterprise Performance. Strategic Management Journal, 28, 1319-1350. https://doi.org/10.1002/smj.640

Teece, D. J., Pisano, G., \& Shuen, A. (1997). Dynamic Capabilities and Strategic Management. Strategic Management Journal, 18, 509-533.

https://doi.org/10.1002/(SICI)1097-0266(199708)18:7<509::AID-SMJ882>3.0.CO;2-Z

Thornhill, S., \& Amit, R. (2003). Learning about Failure: Bankruptcy, Firm Age, and the Resource-Based View. Organization Science, 14, 497-509.

https://doi.org/10.1287/orsc.14.5.497.16761

Wade, M., \& Hulland, J. (2004). Review: The Resource-Based View and Information Systems Research: Review, Extension, and Suggestions for Future Research. MIS Quarterly, 28, 107-142. https://doi.org/10.2307/25148626

Wang, C. L., \& Ahmed, P. K. (2007). Dynamic Capabilities: A Review and Research Agenda. International Journal of Management Reviews, 9, 31-51.

https://doi.org/10.1111/j.1468-2370.2007.00201.x

Wiklund, J., Patzelt, H., \& Shepherd, D. A. (2009). Building an Integrative Model of Small Business Growth. Small Business Economics, 32, 351-374.

https://doi.org/10.1007/s11187-007-9084-8

Winter, S. (2003). Understanding Dynamic Capabilities. Strategic Management Journal, 24, 991-995. https://doi.org/10.1002/smj.318

World Bank (2017). Mobile Money in Somalia: Household Survey and Market Analysis. https://www.mfw4a.org/sites/default/files/resources/Mobile Money in Somalia.WBan pdf 